DOI: https://doi.org/10.32839/2304-5809/2021-11-99-83

УДК 332.146

Коба О.В.

Національний університет «Полтавська політехніка імені Юрія Кондратюка»

\title{
РОЗВИТОК БУДІВЕЛЬНОЇ ГАЛУЗІ УКРАЇНИ ЯК ЗАПОРУКА СТАЛОГО РОЗВИТКУ НАЦІОНАЛЬНОЇ ЕКОНОМІКИ
}

Анотація. Розвиток будівельної галузі є запорукою стабільного розвитку економіки держави. Дослідження свідчать, що показники діяльності суб’єктів господарювання будівельної галузі України за 2015-2020 роки мали в цілому позитивну динаміку. Зріс внесок будівельної галузі у ВВП країни як в абсолютному, так у відсотковому значенні, збільшувалися обсяги виконаних будівельних робіт, індекс будівельної продукції, кількість діючих суб’єктів господарювання, кількість робочих місць в будівельній галузі. Проте рівень більшості показників суттево відставав від рівня европейських країн. Значні зміни у ведення будівельного бізнесу внесла пандемія COVID-19. У 2020 році відбулося значне зменшення обсягу капітальних інвестицій у будівельну галузь. Залишаються проблемними і потребують вирішення моменти ліквідації, підключення до системи електромереж, якості контролю, реєстрації, оподаткування, інвестування в будівельній галузі.

Ключові слова: будівельна галузь, капітальні інвестиції, будівельний бізнес, обсяг будівельних робіт.

Koba Olena

Yuri Kondratyuk Poltava Polytechnic National University

\section{DEVELOPMENT OF THE CONSTRUCTION INDUSTRY OF UKRAINE AS A GUARANTEE OF SUSTAINABLE DEVELOPMENT OF THE NATIONAL ECONOMY}

Summary. The development of the construction industry is the key to stable development of the state economy. Research shows that the performance of economic entities in the construction industry of Ukraine for 2015-2020 had a generally positive trend. The contribution of the construction industry to the country's GDP has increased both in absolute and percentage terms, the volume of construction work performed, the index of construction products, the number of operating entities, and the number of jobs in the construction industry have increased. However, the level of most indicators lagged significantly behind the level of European countries. The COVID-19 pandemic has made significant changes in the construction business. Its consequences have provoked the rapid introduction of new efficient technologies in construction, the use of robotics, the use of innovative safe for humans and environmental materials, the development of green, modular and outdoor construction, the expansion of housing construction. These trends in the construction industry are rapidly changing the world market and require solutions to problems that hinder its development in Ukraine, including: lack of financial resources; insufficient demand for products and services of construction companies; constant growth of production costs; imperfect pricing system; low qualification of employees; insufficient connection between science and practice; low level of research and implementation of the latest developments; high degree of depreciation of fixed assets; bureaucratic obstacles to the implementation of construction projects. To eliminate them, it is necessary to modernize the construction infrastructure; to introduce modern forms of providing enterprises of the construction industry with mechanization, advanced innovative technologies; update their material and technical base; expand sales of construction products; financing of projects (development of mortgage lending for the population, investment support programs for construction by the state and the private sector); to attract new highly qualified personnel; to monitor the quality of construction and installation work performed.

Keywords: construction industry, capital investments, construction business, volume of construction works.

$\Pi$ остановка проблеми. Ефективність національної економіки залежить від розвитку галузей матеріального виробництва, зокрема, будівельної. Будівництво забезпечуе створення нових і відновлення вже діючих основних засобів суб'єктів господарювання та населення, завдяки будівництву, відбувається нарощення обсягів виробництва будівельних матеріалів, обладнання, металургії, машинобудування, деревообробної промисловості, надртохімії, енергетики, транспорту. Розвиток будівельної галузі сприяє зростанню показників інших галузей, впливає на стан економіки країни в цілому, що обумовлюе необхідність забезпечення його стабільної позитивної динаміки. Вирішення цього питання забезпечуеться проведенням грунтовного аналізу сучасного стану галузі, виявленням проблем, що перешкоджають iї розвитку, та визначенням шляхів їх усунення.

Аналіз останніх досліджень і публікацій. Тенденції розвитку будівельної галузі в Україні $\epsilon$ предметом досліджень багатьох вітчизняних науковців, зокрема I. Адамської, H.I. Верхоглядової, В.Т. Вечерова, І.В. Волохової, В.Ф. Гамалія, А.Ф. Гойка, В.І. Дмитренка, А.Г. Жовтяк, Т.Є. Іваницької, Ж.Л. Крисько, Л.І. Куликової, О.В. Латишевої, Л.Г. Ліпич, К.А. Мамонова, Т.В. Момот, В.О. Онищенка, Н. А. Петрищенко, С.А. Романчука, Б. Г. Сеніва, Р.Б. Тяна, О.І. Угоднікової, В.Г. Федоренка, Л.М. Шутенка та ін.

Проте, вивчення сучасного стану та перспектив розвитку будівельної галузі, з точки зору забезпечення сталого розвитку економіки держави, залишається актуальним завданням сьогодення.

Стан будівельної галузі, на думку Богінської Л.О., є індикатором макроекономічного клімату в країні, оскільки саме будівельна сфера активно реагуе на негативні та позитивні зміни економічної ситуащіï. Автор вважае, що розвиток будівництва залежить від зовнішніх (функціонування політичної та економічної систем, діючої правової бази, роз- 
витку відносин власності, формування галузевого ринку тощо) та внутрішніх умов (організація та технологія будівельного виробництва) [1].

Як відзначає Дмитренко B.I., на сучасному етапі будівельна галузь не $є$ конкурентоспроможною. На його думку, лише на регіональному рівні підприемства будівельної галузі центральних районів та великих міст у зв'язку з їх значними потужностями i інвестиційною привабливістю відіграють провідну роль, а на глобальному рівні будівельній галузі України бракуе для цього необхідних фрінансових та організаційних перетворень [2].

На відставанні можливостей будівельного комплексу від сучасних вимог ринку практично за всіма параметрами (товарним, господарським, матеріально-технічним, соціальним та ін.) наголошують Щурко У.В., Лобай Р.Р. [3]. На їхню думку, проблеми та перешкоди розвитку будівництва сповільнюють економічний розвиток країни, погіршують її конкурентну позицію.

Дослідження, проведені Латишевою О.В. та Сайко А.Д. [4] свідчать, що така ситуація обумовлена збільшенням ступеню зносу основних засобів, зменшенням обсягів введення нових основних засобів, зниженням рентабельності діяльності будівельних підприемств.

Поліпшення роботи будівельних підприемств з метою забезпечення їх конкурентоспроможності, як стверджують Жовтяк Г.А., Волохова I.В., можливе за рахунок оновлення основних засобів; впровадження інноващійних будівельних технологій; підвищення якості будівельної продукції; вдосконалення управління, розширення горизонту планування; впровадження довгострокових програм фрінансування будівництва; сприяння розвитку кластерних утворень [5]. Крім џього, вважає Адамська I., для подальшого розвитку будівельна галузь потребує залучення інвести- цій, нових кваліфікованих кадрів, упровадження новітніх технологій у виробництво [6].

Виділення не вирішених раніше частин загальної проблеми. Пандемія COVID-19 внесла суттєві зміни у ведення будівельного бізнесу: від планування та закриття проектів до найму працівників і зустрічей 3 кліентами. Ї̈ наслідки спровокували стрімке впровадження в будівництво нових ефрективних технологій (3D візуалізація майбутніх проектів у навколишньому середовищі, автоматизований обмір будівель, швидке та доступне моделювання архітектурноконструкційних змін, індрормаційне моделювання будівель), використання робототехніки, застосування інноваційних безпечних для людини і екологічних матеріалів, розвиток зеленого, модульного та виїзного будівництва, розширення житлового будівництва. Ці тенденції будівельної галузі швидко змінюють світовий ринок і вимагають дослідження цілого спектру питань, що стосуються сучасного стану, проблем та перспектив розвитку будівельної галузі Україні.

Мета статті. Метою даної роботи є аналіз динаміки показників діяльності суб'єктів господарювання будівельної галузі України, з'ясування особливостей та перспектив їі розвитку, визначення фракторів, що йому перешкоджають.

Виклад основного матеріалу. Будівельна галузь України - стратегічно важлива для розвитку національної економіки, який визначається динамікою обсягів ВВП, що формується у всіх ïi copepax, зокрема і в будівництві. Результати дослідження свідчать, що протягом 2015-2020 років внесок будівельної галузі у ВВП країни як в абсолютному, так у відсотковому значенні мав позитивну динаміку (таблиця 1). Проте його рівень значно відставав від аналогічного показника європейських країн.

Частка будівельної галузі у загальному ВВП України у 2015-2020 роках

\begin{tabular}{|l|c|c|c|c|c|c|}
\hline \multicolumn{1}{|c|}{ Рік } & $\mathbf{2 0 1 5}$ & $\mathbf{2 0 1 6}$ & $\mathbf{2 0 1 7}$ & $\mathbf{2 0 1 8}$ & $\mathbf{2 0 1 9}$ & $\mathbf{2 0 2 0}$ \\
\hline $\begin{array}{l}\text { Валовий внутрішній продукт } \\
\text { усього, млн. грн. }\end{array}$ & 1988544 & 2385367 & 2983882 & 3560596 & 3977198 & 4191864 \\
\hline ВВП будівництва, млн. грн. & 38928 & 47457 & 64431 & 81259 & 107430 & 120274 \\
\hline $\begin{array}{l}\text { Частка будівельної галузі } \\
\text { у загальному ВВП, \% }\end{array}$ & 1,96 & 1,99 & 2,16 & 2,28 & 2,70 & 2,87 \\
\hline
\end{tabular}

Джерело: розроблено автором за даними Державної служби статистики України [7]

Обсяг виконаних будівельних робіт за видами продукції за 2015-2020 роки

\begin{tabular}{|c|c|c|c|c|c|c|c|}
\hline Показник & $\begin{array}{c}\text { Одиниця } \\
\text { виміру }\end{array}$ & 2015 & 2016 & 2017 & 2018 & 2019 & 2020 \\
\hline \multirow{2}{*}{ Будівництво всього, } & млн. грн. & 57515 & 73726,9 & 105682,8 & 141213,1 & 181697,9 & 202080,8 \\
\hline & $\%$ & 100 & 100 & 100 & 100 & 100 & 100 \\
\hline \multirow{2}{*}{ Інженерні споруди } & млн. грн. & 28607,5 & 35620,5 & 52873,2 & 74421,5 & 98108,6 & 121455,2 \\
\hline & $\%$ & 49,74 & 48,31 & 50,03 & 52,70 & 54,00 & 60,1 \\
\hline \multirow{2}{*}{ Будівлі } & млн. грн. & 28907,5 & 38106,4 & 52809,6 & 66791,6 & 83589,3 & 80625,6 \\
\hline & $\%$ & 50,26 & 51,69 & 49,97 & 47,30 & 46,00 & 39,9 \\
\hline \multicolumn{8}{|l|}{ у тому числі } \\
\hline \multirow{2}{*}{ житлові } & млн. грн. & 13908,8 & 18012,8 & 23730 & 29344,8 & 33208,8 & 29083,6 \\
\hline & $\%$ & 24,18 & 24,43 & 22,45 & 20,78 & 18,28 & 14,39 \\
\hline \multirow{2}{*}{ нежитлові } & млн. грн. & 14998,7 & 20093,6 & 29079,6 & 37446,8 & 50380,5 & 51542 \\
\hline & $\%$ & 26,08 & 27,25 & 27,52 & 26,52 & 27,73 & 25,51 \\
\hline
\end{tabular}

Джерело: розроблено автором за даними Державної служби статистики України [7] 


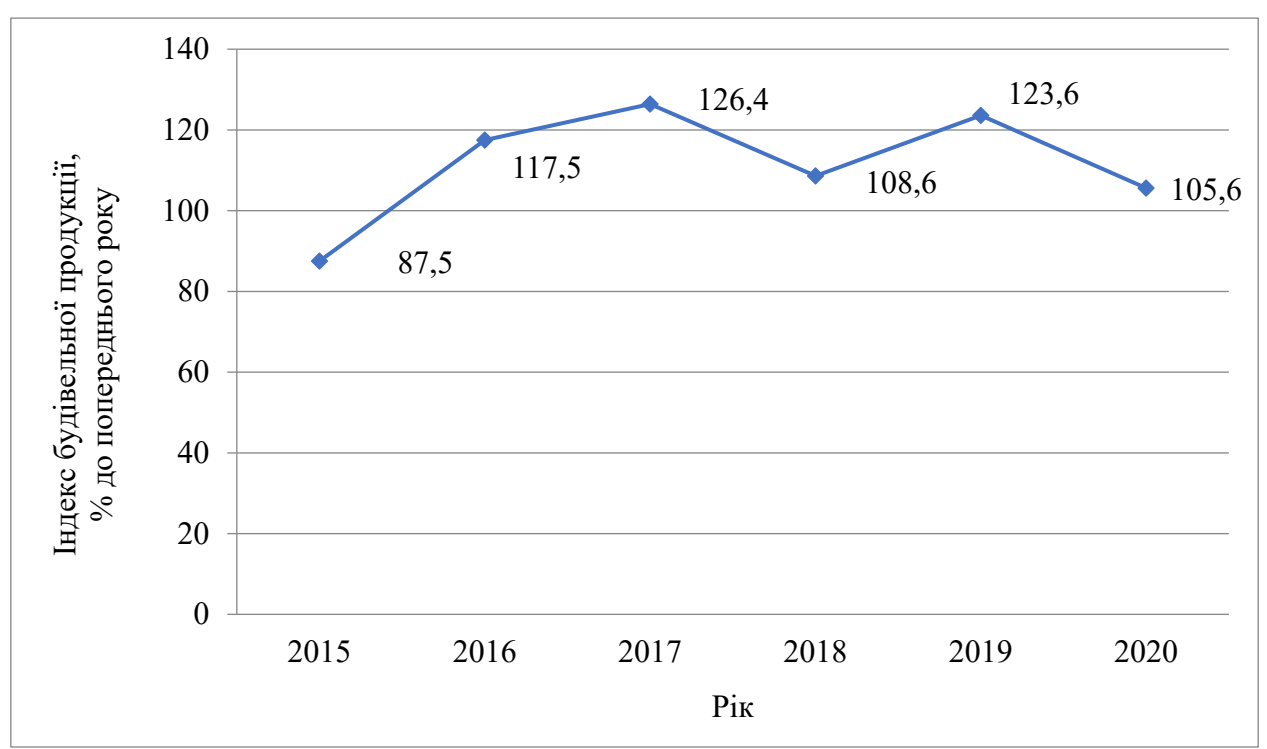

Рис. 1. Індекси будівельної продукції в Україні у 2015-2020 роках, \% до попереднього року Джерело: розроблено автором за даними Державної служби статистики України [7]

Зростання частки будівництва в структурі ВВП е наслідком збільшення в періоді, що аналізуеться, обсягів виконаних будівельних робіт. Він за 2015-2020 роки зріс більше, ніж у 3,5 рази (таблиця 2). При цьому його структура за видами будівельної продукції змінювалася несуттево. За підсумками 2020 року в Україні виконано будівельних робіт на суму 202080,8 млн. грн., що на 144565,8 млн. грн. більше, ніж у 2015 році, індекс будівельної продукції по відношенню до 2019 року склав 105,6\% (рисунок 1) [7]. Нове будівництво у 2020 році становило - $36 \%$, від загального обсягу виконаних будівельних робіт, реконструкція та технічне переоснащення $-37,9 \%$, капітальний і поточний ремонти $-36,9 \%$. Лідерами будівельної галузі за обсягами виробництва є Одеська, Дніпропетровська, Харківська, Київська, Вінницька, Донецька, Полтавська області.

Позитивним е також зростання кількості діючих суб’ектів господарювання в будівельній галузі (таблиця 3).

Так, у 2015 році вона становила 53128 тис. одиниць, це складае $2,79 \%$ від загальної кількості суб'єктів господарювання. У 2016 році через фінансову кризу відбулося різке скорочення кількості суб'ектів господарювання у будівництві на 8,92\% до 50208 одиниць. Проте, вже з 2017 року почалося зростання даного показника і у 2020 році порівняно з 2016 роком він збільшився на 6718 одиниць, або на 13,38\% та перевищив рівень 2015 року. Частка ж суб'єктів господарювання будівельної галузі у загальній їх кількості за 2015-2020 роки змінилася несуттево (на $0,09 \%$ ).

Будівельна галузь в Україні створюе велику кількість робочих місць, при цьому даний показник з року в рік зростае (таблиця 4).

Ефрективність діяльності будівельної галузі залежить від іï інвестування. Капітальні інвестиції у будівельну галузь за період 2015-2019 роки щороку зростали (таблиця 5). Однак у 2020 році відбулося зменшення обсягу капітальних інвестицій у будівельну галузь в 1,6 разів порівняно 32019 роком. Причиною таких змін варто вважати наслідки локдауну у зв'язку з пандемією COVID-19.

Як свідчать показники України у рейтингу Doing Business (таблиця 6), залишаються проблемними моменти ліквідації, підключення до системи електромереж, якості контролю, реестрації, оподаткування, інвестування в будівельній галузі [8].

Таким чином, незважаючи на те, що протягом 2015-2020 років в цілому спостерігаеться позитивна динаміка показників діяльності будівельної галузі в Україні, рівень ії розвитку не відповідає рівню європейських країн. Це пов'язано з наявністю ряду проблем, серед яких варто виділити:

- нестачу фрінансових ресурсів;

- недостатній попит на продукцію та послуги будівельних підприемств;

- постійне зростання собівартості продукції, яке приводить до підвищення рівня збитковості підприемств та зниження рентабельності їх діяльності;

Кількість суб'єктів господарювання будівельної галузі у 2015-2020 роках

\begin{tabular}{|l|c|c|c|c|c|c|}
\hline \multicolumn{1}{|c|}{ Рік } & $\mathbf{2 0 1 5}$ & $\mathbf{2 0 1 6}$ & $\mathbf{2 0 1 7}$ & $\mathbf{2 0 1 8}$ & $\mathbf{2 0 1 9}$ & $\mathbf{2 0 2 0}$ \\
\hline $\begin{array}{l}\text { Кількість діючих суб'єктів господарювання, } \\
\text { одиниць }\end{array}$ & 1974318 & 1865530 & 1805059 & 1839593 & 1941625 & 1973577 \\
\hline 3 них у будівництві & & & & & & \\
\hline одиниць & 55128 & 50208 & 50261 & 52531 & 56855 & 56926 \\
\hline $\begin{array}{l}\text { у \% до загального показника кількості } \\
\text { діючих суб'ектів господарювання }\end{array}$ & 2,79 & 2,69 & 2,78 & 2,86 & 2,93 & 2,88 \\
\hline
\end{tabular}

Джерело: розроблено автором за даними Державної служби статистики України [7] 
Кількість зайнятих працівників у суб'ектів господарювання будівельної галузі за 2015-2020 роки, млн. грн.

\begin{tabular}{|c|c|c|c|c|c|}
\hline \multirow{3}{*}{ Рік } & \multirow{3}{*}{$\begin{array}{c}\text { Кількість зайнятих } \\
\text { працівників } \\
\text { у суб'єктів } \\
\text { господарювання, } \\
\text { тис. осіб }\end{array}$} & \multicolumn{4}{|c|}{ У тому числі/ } \\
\hline & & \multicolumn{2}{|c|}{ підприемства } & \multicolumn{2}{|c|}{ фізичні особи-підприемці } \\
\hline & & тис. осіб & $\begin{array}{c}\text { y \% до загального } \\
\text { показника }\end{array}$ & тис. осіб & $\begin{array}{c}\text { y \% до загального } \\
\text { показника }\end{array}$ \\
\hline 2015 & 282,5 & 248,1 & 4,1 & 34,4 & 1,5 \\
\hline 2016 & 283,9 & 247,0 & 4,2 & 36,9 & 1,6 \\
\hline 2017 & 293,7 & 257,8 & 4,3 & 35,9 & 1,5 \\
\hline 2018 & 312,3 & 272,2 & 4,5 & 40,1 & 1,6 \\
\hline 2019 & 344.5 & 301,2 & 4,6 & 43,3 & 1,7 \\
\hline 2020 & 329,0 & 287,3 & 4,4 & 41,8 & 1,6 \\
\hline
\end{tabular}

Джерело: розроблено автором за даними Державної служби статистики України [7]

Таблиця 5

Капітальні інвестиції у будівництво за 2015-2020 роки, млн. грн.

\begin{tabular}{|c|c|c|c|c|c|c|}
\hline Рік & $\mathbf{2 0 1 5}$ & $\mathbf{2 0 1 6}$ & $\mathbf{2 0 1 7}$ & $\mathbf{2 0 1 8}$ & $\mathbf{2 0 1 9}$ & $\mathbf{2 0 2 0}$ \\
\hline Капітальні інвестиції & 43463,7 & 44444,0 & 52176,2 & 55993,9 & 62346,6 & 39614,9 \\
\hline
\end{tabular}

Джерело: розроблено автором за даними Державної служби статистики України [7]

Позиції України в рейтингу Doing Business у 2015-2020 роках

Таблиця 6

\begin{tabular}{|c|l|c|c|c|c|c|c|}
\hline \multirow{2}{*}{$\begin{array}{c}\text { № } \\
\text { п/п }\end{array}$} & \multicolumn{5}{|c|}{ Показник } & \multicolumn{5}{c|}{ Позиця України в рейтингу Doing Business } \\
\cline { 3 - 8 } & & $\mathbf{2 0 1 5}$ & $\mathbf{2 0 1 6}$ & $\mathbf{2 0 1 7}$ & $\mathbf{2 0 1 8}$ & $\mathbf{2 0 1 9}$ & $\mathbf{2 0 2 0}$ \\
\hline 1 & Зручність ведення бізнесу & 61 & 83 & 80 & 76 & 71 & 64 \\
\hline 2 & Реестрація бізнесу & 20 & 30 & 20 & 52 & 56 & 61 \\
\hline 3 & Отримання дозволу на будівництво & 128 & 140 & 140 & 35 & 30 & 20 \\
\hline 4 & Підключення до системи електромереж & 61 & 137 & 130 & 128 & 135 & 128 \\
\hline 5 & Реестрація власності & 37 & 61 & 63 & 64 & 63 & 61 \\
\hline 6 & Отримання кредитів & 45 & 19 & 20 & 29 & 32 & 37 \\
\hline 7 & Захист інвесторів & 65 & 88 & 70 & 81 & 72 & 45 \\
\hline 8 & Оподаткування & 74 & 107 & 84 & 73 & 54 & 65 \\
\hline 9 & Міжнародна торгівля & 63 & 109 & 115 & 119 & 78 & 74 \\
\hline 10 & Забезпечення виконання контрактів & 146 & 98 & 81 & 82 & 57 & 63 \\
\hline 11 & Ліквідація підприемства & 142 & 141 & 150 & 149 & 145 & 146 \\
\hline
\end{tabular}

Джерело: розроблено автором за даними [8]

- недосконалу систему ціноутворення;

- низьку квалірікащію працівників, яка частково зумовлена низьким рівнем будівельної освіти, недостатнім зв'язком науки та практики, низьким рівнем новітніх розробок та досліджень [9];

- втрату профресійних будівельників через виїзд за кордон [9; 10];

- високий ступінь зносу основних фондів, їх занедбаність через відсутність інвестиційного попиту;

- бюрократичні перешкоди на шляху реалізації проектів [2].

Висновки i пропозиції. Проведені дослідження свідчать, що, незважаючи на пози- тивну динаміку будівельної галузі протягом 2015-2020 років, в Україні наявні проблеми, які стримують ㄲï розвиток. Для покращення результатів діяльності підприємств будівельної галузі України необхідні: модернізація будівельної індраструктури; впровадження сучасних форм забезпечення підприемств будівельної галузі засобами механізації, передових інноваційних технологій; оновлення їх матеріально-технічної бази; розширення збуту будівельної продукції, фрінансування проектів; залучення нових висококвалірікованих кадрів; моніторинг якості виконаних будівельно-монтажних робіт.

\section{Список літератури:}

1. Богінська Л.О. Стан та перспективи розвитку будівельної галузі України. Еконолічні студї. 2018. № 2. C. $25-28$.

2. Дмитренко В.I. Проблеми та перспективи розвитку підприемств будівельної галузі. Вчені записки Універсиmemy "КРОК». 2020. № 2(58). C. 120-127.

3. Щурко У.В., Лобай Р.Р. Перспективи та перешкоди ефективному розвитку будівельної галузі в Україні. Проблель развития внешнеэконолических связей и привлечения иностранных инвестиций: региональный аспект. 2014. Том 1. С. 427-432.

4. Латишева О.В., Сайко А.Д. Будівельна галузь України: сучасний стан та їі роль у забезпеченні сталого розвитку національної економіки. Еконолічний вісник Донбасу. 2019. № 2(56). С. 66-73. 
5. Жовтяк Г.А., Волохова І.В. Стан та перспективи розвитку підприемств будівельної галузі. Вчені записки ТНУ ілені В.I. Вернадського. Серія : Еконоліка і управління. 2020. Том 31 (70). № 6. С. 50-55.

6. Адамська I. Сучасний стан й тенденщії розвитку будівельної галузі України. Галицький еконолічний вісник. 2019. № 5(60). С. 7-15.

7. Діяльність будівельних підприемств. Державна служба статистики України. URL: https://ukrstat.org/uk/ operativ/menu/menu_u/bud.htm (дата звернення: 30.10.2021).

8. Doing Business 2020 / International Bank for Reconstruction and Development. URL: https://www.doingbusiness.org/ content/dam/doingBusiness/media/Annual-Reports/English/DB2019-report_web-version.pdf (дата звернення: 30.10.2021).

9. Кулікова Л.В. Сучасні тенденції розвитку будівельних підприємств. Інвестицї: практика та досвід. 2018. № 8. С. 52-55.

10. Лучко Г.Й., Когут І.В. Актуальні проекти стратегічного розвитку будівельної галузі України. Eфбективна еконоліка. 2020. № 8. URL: http://www.economy.nayka.com.ua/?op=1\&z=8108 (дата звернення: 30.10.2021).

\section{References:}

1. Bohinska L.O. (2018) Stan ta perspektyvy rozvytku budivelnoi haluzi Ukrainy [Status and prospects of development of the construction industry of Ukraine]. Economic studies, no. 2, pp. 25-28.

2. Dmytrenko V.I. (2020) Problemy ta perspektyvy rozvytku pidpryiemstv budivelnoi haluzi [Problems and prospects of development of construction industry enterprises]. Scientific notes of KROK University, no. 2(58), pp. $120-127$.

3. Shchurko U.V., Lobai R.R. (2014) Perspektyvy ta pereshkody efektyvnomu rozvytku budivelnoi haluzi v Ukraini [Prospects and obstacles to the effective development of the construction industry in Ukraine]. Problems of development of foreign economic relations and attraction of foreign investments: regional aspect, vol. 1, pp. 427-432.

4. Latysheva O.V., Saiko A.D. (2019) Budivelna haluz Ukrainy: suchasnyi stan ta yii rol u zabezpechenni staloho rozvytku natsionalnoi ekonomiky [Construction industry of Ukraine: current state and its role in ensuring sustainable development of the national economy]. Economic Bulletin of Donbass, no. 2(56), pp. 66-73.

5. Zhovtiak H.A., Volokhova I.V. (2020) Stan ta perspektyvy rozvytku pidpryiemstv budivelnoi haluzi [Status and prospects of development of construction companies]. Scientific notes of TNU named after V.I. Vernadsky. Series: Economics and Management, vol. 31 (70), no. 6, pp. 50-55.

6. Adamska I. (2019) Suchasnyi stan y tendentsii rozvytku budivelnoi haluzi Ukrainy [Current state and development trends of the construction industry of Ukraine]. Galician Economic Bulletin, no. 5(60), pp. 7-15.

7. Derzhavna sluzhba statystyky Ukrainy (2021) Diialnist budivelnykh pidpryiemstv [Activities of construction companies]. Available at: https://ukrstat.org/uk/operativ/menu/menu_u/bud.htm (accessed 30 October 2021).

8. International Bank for Reconstruction and Development (2020) Doing Business 2020. Available at: https://www.doingbusiness.org/content/dam/doingBusiness/media/Annual-Reports/English/DB2019-report_webversion.pdf (accessed 30 October 2021).

9. Kulikova L.V. (2018) Suchasni tendentsii rozvytku budivelnykh pidpryiemstv [Current trends in the development of construction companies]. Investments: practice and experience, no. 8, pp. 52-55.

10. Luchko H.Y., Kohut I.V. (2020) Aktualni proekty stratehichnoho rozvytku budivelnoi haluzi Ukrainy [Current projects of strategic development of the construction industry of Ukraine]. Efficient economy, no. 8. Available at: http://www.economy.nayka.com.ua/?op=1\&z=8108 (accessed 30 October 2021). 